\title{
Examining the impact of Sustainability Accounting on the Financial Reporting -A Field Study-
}

\author{
Mohamed M. A. Khodair \\ Accounting and Auditing Department \\ Faculty of Commerce-Ain shams University
}

\begin{abstract}
This paper investigates the impacts of sustainability accounting on corporate financial reporting. As sustainability reporting is a more comprehensive tool than the environmental and social reports. A survey was conducted on a sample of 300 Egyptian listed companies.1200 questionnaires were distributed to managers, accountants, and auditors. 912 questionnaires were returned with a satisfying response rate of $76 \%$. It was found that there is a statistically significant impact of sustainability accounting elements on financial reporting. The total impact of sustainability accounting on financial reporting is weighted by $43.3 \%$. Environmental elements of sustainability accounting explain about $0.243 \%$ of the variations in the financial reporting variable, the social elements explain about $0.235 \%$, and the economic elements explain about $0.352 \%$ of the variations in the financial reporting. It also indicates that implementing sustainability accounting have barriers represented mostly in the management unawareness of the importance of sustainability accounting, consequently management avoidance of reporting its social and environmental activities, and finally the absence of imposing deterrent penalties for companies refraining social and environmental responsibilities reporting.
\end{abstract}

Key words:

Sustainability Reporting, Sustainability Accounting, Financial Reporting

\section{I.Introduction}

Sustainability reporting is a new concept, it refers to how companies deal with significant financial and non-financial issues or activities including environmental, social and economic issues and the potential impacts of opportunities and challenges on the future performance of the company (Rinaldi, and Ureman, 2009). The sustainability report takes several names such as corporate social report, corporate responsibility report, social and community report. It is noted that traditional financial reporting system is no longer efficient to comprehensively represent the overall firms' activities including nonfinancial activities. Firms have adapted to the demanding for more sustainable reporting on the company's economic, environmental and social performance by voluntarily sustainability reporting disclosure. The International Survey on Environmental Reporting conducted by the 
KPMG 2015 stated that the rate of reporting has increased from $28 \%$ to $73 \%$ between the years $2002-2015$. The increase in sustainability reporting is due to the mounting alertness of the importance of sustainability reporting for the stakeholders as well as to the firms. Under the multiple dimensions' approach for sustainability reporting; there is a number of basic models to report the company performance in the area of sustainable development that are summarized in the following reports: (Shanan, Ali, A., 2017)

- The statement of adjusted profit by the commitment of responsibility about sustainable development.

- The adjusted balance sheet statement by the commitment of responsibility about sustainable development.

- The balance sheet of the impacts lack of commitment to sustainable development.

- The multiple dimensioned report of environmental and social performance.

\section{Problem Statement}

It is noted recently that most of so many stakeholders show deep concerns about environmental and social performance of the organization internally and externally. The external parties who are impacted by the sustainable performance of the organization include the community in which the organization work and serve, environmental activity groups, suppliers, clients, investors and shareholders. Organizations are working under different kinds of pressure to engage the environmental and social dimensions side by side to economic dimension in order to reduce environmental impacts.

These dimensions require accountants to pay the due attention to the internal and external benefits that can be achieved through accounting for sustainable development. Also; the chartered accountants should follow the financial information to verify their veracity and expression on the activity of the organization. Recent study aims to shed the light on following points:

- The importance of sustainability accounting.

- The dimensions of sustainability accounting.

- The objectives of sustainability accounting.

- The impacts of sustainability accounting elements on financial reporting.

- The barriers of sustainability accounting implementation. 


\section{Research Objectives}

1) To examine the relationship between sustainability accounting and financial reporting.

2) To examine factors affecting sustainability accounting in practice.

3) To discuss the problems encounter the application of the sustainability accounting elements.

\section{An overview of sustainability accounting}

Sustainability accounting is a useful mean that offers information about the cost of the economic, social and environmental areas to the users of accounting information and decision makers as well. So; it is worthy in this context to shed the light on some aspects that constitute the importance of sustainability accounting.

\subsection{The importance of sustainability accounting}

As a result of the increasing trend disclosure of sustainable development and the introduction of accounting for sustainable development within the general framework of the accounting system; there is an increasing concern of government and civil organizations, international, academics and professional institutions about the environment and sustainable development for the following reasons (Darwish, Abdelnaser, A., 2015)

- The pressures exerted by the international organizations and professional institutions.

- The importance of protecting and developing the environment.

- The society interest of the social role of companies.

- The environmental accounting is now a mandate and inevitable issue under the national and international laws.

Sustainability accounting is an effective mean that enables companies to be more sustainable and it explores the important role of financial information. It extends the monetary value information to include the environmental, social and economic impacts which eventually influence the process of decision making (Hady, Reda, E., 2016). Therefore, the efficient performance of sustainability accounting and consequently reporting can have the following merits:

- It defines stakeholder's relationships that represent sustainability risks and benefits. Besides, external stakeholders are more capable to get knowledge about the true value of the company (Rajan, Varaun, 2016).

- It shows the cost reduction and savings from environmental and social external costs resulted from commitment to sustainability. 
- It is a mean to manage risk as it shed the light and stress on social and environmental risks related to current financial performance. Also it highlights the opportunities available not only the risks.

- Supporting the concepts of governance. It enables efficient corporate governance and management. As it represents a better control over management.

- It provides a benchmarking tool to evaluate sustainability performance. Besides it reports the financial and non-financial performance.

- It enables potential cost savings and comprehensive risk management.

\subsection{The objectives of sustainability accounting:}

Sustainability accounting is an effective mechanism to achieve the following objectives :( Badawy, M., and Albeltagy, Y., 2013)

- Preparing data about sales and total costs that aims to preserve and protect the environment for each financial period. This enables corporate to follow cost behaviour and fluctuations during time and to make appropriate actions.

- Preparing reports about cultural, social and environmental activities to reflect corporate commitment and compliance with environmental and social legislations.

- Declaring of corporate environmental and social responsibility to guarantee the goal of continuity.

- Shedding the light on the benefits and social and environmental savings for every financial period.

\section{Literature review}

Theories that explain the increased demand and calls for sustainability reporting are so many. From which are the agency theory and the stakeholder theory. According to the agency theory, the shareholders are the owners (principal) while the management is the representative (proxy or agent). So; management on making every single decision should take into consideration the interest of the stakeholders.

With respect to the stakeholder theory; there must be a social contract between the firm and stakeholders; this contract will guarantee the survival and security for stakeholders on the long run through the social and environmental commitment. Also; stakeholders must have adequate knowledge about the rules and regulations that imposed on practices of the company. This is called institutional circumstances, 
which form the standards that firms are adapting and following. It is noteworthy that firms that work in similar circumstances will have by nature similar frameworks and modalities (Coates, J., 2013).

While the shareholder's theory focuses on the relationship of the company with each category of stakeholder separately. Despite their conflict; there is one pattern of social contract according to legitimacy theory but there are multiple patterns of social contact in the shareholder's theory.

It is stated in some literature that sustainability accounting auditing is in much agreement with the corporate theory. Regarding the company is a social entity with a human role and social responsibilities that must be performed to all classes of the community including shareholders, employees, debtors, clients and governmental and syndicate associations. The management role encompasses the use of economic and social resources in the appropriate way to maintain corporate continuity and survival. (Alatoom and Abu Zerr, 2016)

The study of Matar and Elswety (2012) concentrates on the linkage between accounting and the assumption of corporate continuity or sustainability. Which hypothesizes that corporate sustainability is the normal state of economic life cycle. It concludes that evaluating company's economic performance cannot be done in isolation from its social and political effects on the environment. And it eventually reported that; despite considering these aforementioned effects there is still a gap of expectations needs filling between the type of activities expected by the community and the real activities performed by the company.

The study of Abu Zerr, Afaf, E., 2012 aims to show the importance of the internal auditing role in sustainability. It indicates how sustainability is related to public sector firms in general and to internal auditing in particular. The results of the study pointed out those firms exerting their best to put non-financial measurements under the eye of decision makers. It ends to the important role of internal auditing to assist effective sustainability. It also stated that internal auditing has the 
ability to add value to management by educating managers about recognized sustainability standards and guidelines.

\section{Research Hypotheses}

H1: Sustainability accounting has a statistically significant impact on financial reporting.

H11: The economic elements of sustainability accounting have a statistically significant impact on financial reporting.

H12: The social elements of sustainability accounting have a statistically significant impact on financial reporting.

H13: The environmental elements of sustainability accounting have a statistically significant impact on financial reporting.

$\mathrm{H} 2$ : There are difficulties of sustainability reporting application in practice.

\section{Statistical analysis}

The dependent variable is the financial reporting.

The independent variable is the sustainability accounting. It has three main dimensions: economic, environmental, and social. Each dimension has a number of activities that overlap with each other to achieve the goals of sustainability accounting at last.

\section{7-1 Population of the study:}

The population of the study includes all the industrial firms that are reported in the Egyptian stock exchange (300). The questionnaire survey was sent to 300 of industrial firms including: Food and beverage, chemicals, healthcare and pharmaceuticals, real estate, home and personal products, textiles, automobiles and motor vehicles, communication, building and structure. Of the 1200 questionnaires sent, 912 were returned with an effective response of $76 \%$. The questionnaire was sent to the financial managers, accountants and auditors in each firm. The provided information was assured about privacy. Moreover; Sharing the results of the survey was offered and to acknowledge the contribution of the respondent company to the study

\section{7-2 Data collection:}

The data utilized in this study was obtained through two sources; primary sources and secondary sources. Primary data was collected through developing a questionnaire that contains five sections each include questions for every component of sustainable accounting and the difficulties of application besides the demographic part. 
While the secondary data was collected through the periodicals, annual published reports and through previous studies that have discussed this issue earlier in different ways and in some details.

\section{7-3 Reliability statistics:}

To examine the reliability and stability of the respondents in answering the questions; the researcher used the Cronbach's alpha test:

$\propto_{\text {Cronbach }}=\frac{k}{k-1}\left(1-\frac{\sum_{i=1}^{k} s_{i}^{2}}{S_{t}^{2}}\right)$

\section{Where:}

$\mathrm{K}=$ number of components

$\mathrm{S}_{\mathrm{i}}=$ standard deviation of items

$\mathrm{S}_{\mathrm{t}}=$ standard deviation of total test scores

The value of Cronbach's alpha ranges between 0 and 1 , the value of one indicates a greater internal consistency of the items of the questionnaire on the scale. The accepted value of the test is 0.6 or more. And lower values under the accepted borders indicates unreliable scale (Field, A, 2009).

Table (1): Reliability Statistics

\begin{tabular}{|l|c|c|}
\hline \multicolumn{1}{|c|}{ Sections } & Items & $\begin{array}{c}\text { Cronbach's } \\
\text { alpha }\end{array}$ \\
\hline The whole questionnaire & 62 & $81.9 \%$ \\
\hline Social components & 20 & $72.1 \%$ \\
\hline Environmental components & 15 & $92.3 \%$ \\
\hline Economic components & 15 & $78.7 \%$ \\
\hline $\begin{array}{l}\text { Challenges of accounting sustainability } \\
\text { application }\end{array}$ & 12 & $79.3 \%$ \\
\hline
\end{tabular}

Commenting on table (1) the overall reliability measure is 0.819 with a minimum value 0 and maximum value 1 is considered highly accepted value. It indicates that the variables have relatively high internal consistency. And for all items the Cronbach's alpha is greater than 0.6; So we can conclude that the questionnaire is internally reliable and consistent and no one single part can be omitted without affecting the overall reliability. 


\section{7-4 Descriptive statistics:}

Are used to describe the view points of the respondents about the variables of the study. It includes calculating: the mean, the standard deviation, and the percentages.

Table (2): The Mean and the Standard Deviation for the Social components of sustainability accounting.

\begin{tabular}{|c|c|c|}
\hline Items: social components & Mean & $\begin{array}{l}\text { Standard } \\
\text { deviation }\end{array}$ \\
\hline $\begin{array}{l}\text { 1. Social responsibility is just a random } \\
\text { activity with no definite plans or objectives in } \\
\text { your firm. }\end{array}$ & 4.18 & 0.62 \\
\hline $\begin{array}{l}\text { 2. Your company disclose data about costs } \\
\text { incurred for training employees in published } \\
\text { reports }\end{array}$ & 3.77 & 0.74 \\
\hline $\begin{array}{l}\text { 3. Your company reports on donations and in- } \\
\text { kind assistance to charities }\end{array}$ & 3.65 & 0.6 \\
\hline $\begin{array}{l}\text { 4. Your company is willing to bear any } \\
\text { additional cost in commitment with its social } \\
\text { responsibility }\end{array}$ & 3.63 & 0.71 \\
\hline $\begin{array}{l}\text { 5.Your company publishes information to } \\
\text { handle the problem of unemployment }\end{array}$ & 4.13 & 0.7 \\
\hline $\begin{array}{l}\text { 6. Your company is highly considering } \\
\text { sustainability accounting to handle its social } \\
\text { responsibilities }\end{array}$ & 4.16 & 0.6 \\
\hline $\begin{array}{l}\text { 7. The system of wages and salaries in your } \\
\text { company is fair. }\end{array}$ & 4.22 & 0.67 \\
\hline $\begin{array}{l}\text { 8. Your company misreports any social cost } \\
\text { information that may reduce future cash } \\
\text { flows. }\end{array}$ & 3.91 & 0.7 \\
\hline $\begin{array}{l}\text { 9. Your company's management is pursuing } \\
\text { the objective of improving the working } \\
\text { environment }\end{array}$ & 3.73 & 0.6 \\
\hline $\begin{array}{l}\text { 10. Your company's management aims to } \\
\text { improve the capabilities of the organization. }\end{array}$ & 3.52 & 0.5 \\
\hline $\begin{array}{l}\text { 11. Your company contributes to projects that } \\
\text { serve the community development and } \\
\text { achieve the welfare of individuals. }\end{array}$ & 3.72 & 0.6 \\
\hline $\begin{array}{l}\text { 12. Your company has interest in employees', } \\
\text { health ,education and housing. }\end{array}$ & 3.41 & 0.65 \\
\hline Grand mean & 3.835 & 0.599 \\
\hline
\end{tabular}


The social component of sustainability accounting was tested using 10 statements that has a grand mean of 3.839 and a standard deviation of 0.599 and the relative importance relates to the sixth statement with a mean of 4.16 that express management interest to adopt sustainability accounting to handle its social responsibilities and the least important was management interest in the employees' health, education and housing with a mean of 3.41 .

Table (3): The mean and standard deviation for environmental components of sustainability accounting

\begin{tabular}{|c|c|c|}
\hline Items: environmental components & Mean & $\begin{array}{l}\text { Standard } \\
\text { deviation }\end{array}$ \\
\hline $\begin{array}{l}\text { 11. Your company always considers } \\
\text { environmental impacts on making investment } \\
\text { decisions }\end{array}$ & 3.64 & 0.75 \\
\hline $\begin{array}{l}\text { 12. Your company highly concern about fines } \\
\text { and banishment applied due to neglecting } \\
\text { environmental responsibilities. }\end{array}$ & 4.10 & 0.62 \\
\hline $\begin{array}{l}\text { 13. Your company always include the } \\
\text { environment in its vision, mission and } \\
\text { objectives }\end{array}$ & 3.71 & 0.76 \\
\hline $\begin{array}{l}\text { 14. Your company always support accountants } \\
\text { and encourages them to apply concepts of } \\
\text { environmental accounting in their work. }\end{array}$ & 4.16 & 0.6 \\
\hline $\begin{array}{l}\text { 15. Environmental costs are included in the } \\
\text { balance and income sheets. }\end{array}$ & 3.49 & 0.73 \\
\hline $\begin{array}{l}\text { 16. In your company, does the process of } \\
\text { classifying environmental cost assist to } \\
\text { improve the quality of accounting information } \\
\text { and finally reflect on the financial reporting. }\end{array}$ & 3.75 & 0.67 \\
\hline $\begin{array}{l}17 \text {, Environmental information that your } \\
\text { company provides has the impact on company } \\
\text { reputation and profitability. }\end{array}$ & 3.71 & 0.79 \\
\hline $\begin{array}{l}\text { 18. The consumption of natural resources is } \\
\text { reported in the company's annual report }\end{array}$ & 4.15 & 0.65 \\
\hline $\begin{array}{l}\text { 19. Your company is working on obtaining new } \\
\text { sources of energy. }\end{array}$ & 4.01 & 0.63 \\
\hline $\begin{array}{l}\text { 20. Your company has interest to reduce the } \\
\text { harmful emissions from its activities. }\end{array}$ & 4.40 & \\
\hline $\begin{array}{l}\text { 21. Your company is working on the objective } \\
\text { of achieving savings of energy consumption. }\end{array}$ & 3.62 & 0.62 \\
\hline
\end{tabular}




\begin{tabular}{|l|c|c|}
\hline $\begin{array}{l}\text { 22. Your company has equipments to reduce } \\
\text { environmental pollution. }\end{array}$ & 4.07 & 0.63 \\
\hline $\begin{array}{l}\text { 23. Your company concerns to measure the } \\
\text { environmental costs. }\end{array}$ & 3.96 & 0.77 \\
\hline $\begin{array}{l}\text { 24. Your company concerns about setting } \\
\text { sound measurements for environmental } \\
\text { performance. }\end{array}$ & 4.35 & 0.89 \\
\hline Grand mean & 3.82 & 0.651 \\
\hline
\end{tabular}

The environmental elements of sustainability accounting were tested using 14 (11-24) statements as shown in the previous table, with a grand mean of 3.82 and a standard deviation of 0.651 . The highest importance was given to statement (20) with a mean of 4.40 which reflects the importance of protecting the surrounding environment corporate activities. Followed by statement (23) about firm interest of measuring environmental performance properly and ending with the least important from respondents' views the (21) statement about the objective of achieving savings from energy consumption.

Table (4): The mean and Standard deviation of the economic component of sustainability accounting.

\begin{tabular}{|l|c|c|}
\hline Items of economic component & Mean & $\begin{array}{l}\text { Standard } \\
\text { deviation }\end{array}$ \\
\hline $\begin{array}{l}\text { 25. Your company usually informs about any } \\
\text { potential risks in the future. }\end{array}$ & 3.65 & 0.72 \\
\hline $\begin{array}{l}\text { 26. Your company regularly discloses the } \\
\text { costs of its contribution to support the } \\
\text { development of national economy. }\end{array}$ & 3.82 & 0.70 \\
\hline $\begin{array}{l}\text { 26. The policy of your company respects the } \\
\text { rules of competition. }\end{array}$ & 3.91 & 0.73 \\
\hline $\begin{array}{l}\text { 27. Your company use new mechanisms to } \\
\text { improve the efficiency of operations. }\end{array}$ & 3.72 & 0.72 \\
\hline $\begin{array}{l}\text { 28. Your company exerts efforts in cost } \\
\text { reduction, which maximizes profits. }\end{array}$ & 4.11 & 0.34 \\
\hline $\begin{array}{l}\text { 29. Your company has a sound plan for cost } \\
\text { reduction based on proper economic } \\
\text { concepts. }\end{array}$ & 3.83 & 0,65 \\
\hline $\begin{array}{l}\text { 30. Your company management can properly } \\
\text { manage and control the available resources. }\end{array}$ & 3.77 & 0.76 \\
\hline $\begin{array}{l}\text { 31. Your company disclose the costs incurred } \\
\text { to support the infra structure. }\end{array}$ & 3.97 & 0.66 \\
\hline Grand mean & 3.937 & 0.66 \\
\hline
\end{tabular}


The results indicate that the economic component has a considerable impact on financial reporting with a grand mean of (3.937) and a standard deviation of (0.66). The highest important statement from respondents' point of view is the management interest in cost reduction objective with a mean of 4.11 and the least relates to management disclosure of any potential risks in the future with a mean of (3.65).

Table (5): The Mean and Standard deviation of challenges of sustainability accounting application.

\begin{tabular}{|l|c|c|}
\hline $\begin{array}{l}\text { Items: challenges of the application of } \\
\text { sustainability accounting }\end{array}$ & Mean & $\begin{array}{c}\text { Standard } \\
\text { deviation }\end{array}$ \\
\hline $\begin{array}{l}\text { 32. Absence of an official benchmark to } \\
\text { organize social responsibility issues }\end{array}$ & 3.91 & 0.63 \\
\hline $\begin{array}{l}\text { 33. Lack of penalties for companies that } \\
\text { refrain from reporting their social } \\
\text { responsibility. }\end{array}$ & 3.79 & 0.72 \\
\hline $\begin{array}{l}\text { 34. lack of adequate governmental incentives } \\
\text { for adopting sustainability accounting policies }\end{array}$ & 3.62 & .65 \\
\hline $\begin{array}{l}\text { 35. Your company management may } \\
\text { underestimate the expected returns from } \\
\text { sustainability accounting compared to its } \\
\text { costs. }\end{array}$ & 3.71 & 0.74 \\
\hline $\begin{array}{l}\text { 36. Insufficient finance for training personnel } \\
\text { on the application of reporting sustainability } \\
\text { accounting. }\end{array}$ & 3.62 & 0.82 \\
\hline $\begin{array}{l}\text { 37. Your firm evades reporting social } \\
\text { responsibility that may harm the value of } \\
\text { investments. }\end{array}$ & 4.12 & 0.65 \\
\hline $\begin{array}{l}\text { 38. Your company management doesn't have } \\
\text { interest in the sustainability accounting } \\
\text { reporting and its expected returns. }\end{array}$ & 4.22 & 0.75 \\
\hline $\begin{array}{l}\text { 39. Your company fears that competitors may } \\
\text { misuse the elements reported in the } \\
\text { sustainability accounting reports. }\end{array}$ & 3.61 & 0.80 \\
\hline $\begin{array}{l}\text { 40. Your company finds problems in } \\
\text { measurement of some cost items concerning } \\
\text { elements of sustainability accounting. }\end{array}$ & 4.11 & .69 \\
\hline Grand mean & 0.806 \\
\hline For the previs table; is found & & \\
\hline
\end{tabular}

For the previous table; it is found that the problems investigated about the application of sustainability; were of high significance with a 
mean of (3.856) and a standard deviation of (.806). Results also indicate that in the forefront comes the problem of management unawareness of the importance of sustainability accounting with a mean of (4.22) and a standard deviation of (0.73). While in the last position comes the problems of management's fear from competitors' misuse of the elements reported in the sustainability accounting and the problem of insufficient funds.

Table (6): The mean and standard deviation for financial reporting as the dependent variable.

\begin{tabular}{|l|c|c|}
\hline Items: Financial reporting & Mean & $\begin{array}{c}\text { Standard } \\
\text { deviation }\end{array}$ \\
\hline $\begin{array}{l}\text { 41. The reports provide appropriate } \\
\text { information for the needs of decision makers. }\end{array}$ & 3.87 & 0.6 \\
\hline $\begin{array}{l}\text { 42. Financial reporting provides adequate and } \\
\text { relevant information for making more } \\
\text { informative decisions. }\end{array}$ & 3.95 & 0.93 \\
\hline $\begin{array}{l}\text { 43. Financial reporting offers comparable } \\
\text { information to enable the process of studying, } \\
\text { analysis and making more informative } \\
\text { decisions. }\end{array}$ & 3.42 & 0.84 \\
\hline $\begin{array}{l}\text { 44. Financial reporting increases your firm's } \\
\text { predictive power that is used to set plans and } \\
\text { articulate future policies. }\end{array}$ & 3.74 & 0.97 \\
\hline $\begin{array}{l}\text { 45. Financial reports contain truthful and } \\
\text { credible information in expressing the } \\
\text { phenomena to be reported. }\end{array}$ & 3.72 & 0.86 \\
\hline The grand mean & 3.74 & 0.84 \\
\hline
\end{tabular}

It is obvious that the means of the financial reporting variable ranges from (3.4) to (3.95). It is found that the problem of the relevance of information for making better decision has the most relative importance of a mean of (3.95) and a standard deviation of ( 0.93). And the least relative importance for the statement is the comparability of financial reports with a mean of (3.4) and a standard deviation of (0.84).

Table (7): The results of testing the hypotheses:

\begin{tabular}{|c|l|l|l|c|}
\hline The variable & $\mathrm{R}^{2}$ & $\mathrm{~F}_{\text {cal. }}$ & Sig. & $\begin{array}{c}\text { Statistical } \\
\text { decision }\end{array}$ \\
\hline Sustainability accounting & 0.434 & 54.78 & 0.00 & Reject $\mathrm{H}_{0}$ \\
\hline
\end{tabular}


Table (8): Testing the hypothesis for the elements of sustainability accounting:

\begin{tabular}{|l|l|l|l|c|}
\hline The variable & $\mathrm{R}^{2}$ & $\mathrm{~T}_{\text {cal. }}$ & Sig. & Statistical decision \\
\hline Economic elements & 0.322 & 16.40 & 0.00 & Reject $\mathrm{H}_{0}$ \\
\hline Social elements & 0.256 & 18.9 & 0.00 & Reject $\mathrm{H}_{0}$ \\
\hline Environmental elements & 0.354 & 16.4 & 0.00 & Reject $\mathrm{H}_{0}$ \\
\hline
\end{tabular}

Commenting on the previous table it is clear that $\mathrm{F}_{\mathrm{cal}}(54.78)$ is greater than Ft (3.84) which indicates the overall significance of the elements of sustainability accounting (the significance level is 0.00). The variability of financial reporting is explained by the variability of sustainability accounting elements with a percentage of 0.434 .

Testing the sub-hypotheses from the first hypothesis by the least square method of simple regression:

H11: There is no significant impact of economic element of sustainability accounting on financial reporting.

Table (9): Simple regression results

\begin{tabular}{|l|l|l|l|l|}
\hline The variable & $\mathrm{R}^{2}$ & Sig. & $\mathrm{T}_{\text {cal. }}$ & $\begin{array}{l}\text { Statistical } \\
\text { decision }\end{array}$ \\
\hline Economic element & 0.352 & 0.00 & 16.54 & Reject $\mathrm{H}_{0}$ \\
\hline
\end{tabular}

$\mathrm{H} 21$ : Social elements of sustainability accounting don't have a statistically significant impact on financial reporting.

Table (10): simple regression results

\begin{tabular}{|l|l|l|l|l|}
\hline The variable & $\mathrm{R}^{2}$ & Sig. & $\mathrm{T}_{\text {cal. }}$ & $\begin{array}{l}\text { Statistical } \\
\text { decision }\end{array}$ \\
\hline Social elements. & 0.235 & 0.00 & 17.66 & Reject $\mathrm{H}_{0}$ \\
\hline
\end{tabular}

H31: environmental elements of sustainability accounting don't have a statistically significant impact on financial reporting.

Table (11): simple regression results

\begin{tabular}{|l|l|l|l|l|}
\hline The variable & $\mathrm{R}^{2}$ & Sig. & $\mathrm{T}_{\text {cal. }}$ & $\begin{array}{l}\text { Statistical } \\
\text { decisions }\end{array}$ \\
\hline $\begin{array}{l}\text { Environmental } \\
\text { elements. }\end{array}$ & 0.243 & 0.00 & 18.67 & Reject $\mathrm{H}_{0}$ \\
\hline
\end{tabular}


Testing the second hypothesis:

$\mathrm{H} 2$ : There is no significant impact of the problems encounter the application of sustainability accounting.

Table (12): Results of testing the second hypothesis.

\begin{tabular}{|l|c|c|c|}
\hline The variable & $\mathrm{T}_{\text {cal }}$ & Sig & $\begin{array}{l}\text { Statistical } \\
\text { decision }\end{array}$ \\
\hline $\begin{array}{l}\text { Problems and hardships in the } \\
\text { application of sustainability accounting } \\
\text { elements }\end{array}$ & 3.29 & 0.00 & Reject $\mathrm{H}_{0}$ \\
\hline
\end{tabular}

From the data in the previous table; it is found that $\mathrm{T}_{\mathrm{cal}}$ (3.29) is greater than $\mathrm{T}_{\text {tab. }}$ (1.658). So; there are significant difficulties in the application of sustainability accounting elements with a level of significance at 0.00 that is less than the required level (0.05).

\section{The results of the study}

1) The study revealed that there is a statistically significant impact of environmental elements of sustainability accounting on financial reporting with a mean of (3.937) and a standard deviation of (0.48).

2) The results indicate that environmental elements change explain about $0.243 \%$ of the variations in the financial reporting.

3) Relating to environmental elements the study shows that companies support accountants to engage environmental concepts in their wok and companies are keen to report the consumption of natural resources in annual reports; these eventually affects firms' reputation positively.

4) There is a statistically significant impact of social elements of sustainability accounting on financial reporting with a mean of (3.835) and a standard deviation of (0.599). The variations in the social elements explains about $0.235 \%$ of the variations in financial reporting.

5) The study indicates that from the social elements comes the fairness of wages and salaries' system in the first rank of importance, and firm publishing information about unemployment, willingness to handle additional costs related to social responsibilities.

6) There is a statistically significant impact of economic elements of sustainability accounting on financial reporting with a mean of (3.847) and a standard deviation of (0.66). 
7) In the first rank of importance from economic elements of sustainability accounting is the efforts exerted to cost reduction aim, disclosure of costs incurred to support infrastructure, respect of completion rules, having proper plans to cost reduction, ending with disclosing information about any potential risks in the future.

8) Sustainability accounting implementation does have barriers represented fundamentally in the following points:

- Management unawareness of the importance of sustainability accounting and its expected returns,

- lack of measurements for some cost items related to sustainability accounting,

- absence of a benchmark to organize social responsibility issues,

- lack of deterrent penalties for companies refraining from disclosing their social responsibilities.

\section{Recommendations}

1) It is necessary to disseminate a greater awareness to the importance of sustainability reporting and its role of revealing the economic, social and environmental activities of the companies and impacts on the surrounding environment.

2) To put and develop governmental and taxation incentives to adopt sustainability accounting policies.

3) Enacting the necessary legislation that imposes deterrent penalties for companies that refrain from disclosing sustainable development activities.

4) There should be allocation of sufficient financial resources to train and rehabilitate staff to implement sustainable development.

\section{References:}

Al-Attom, Radi, O. And Abu Zerr, Afaf, E., (2016), 'An approach for auditing sustainable accounting using analytical procedures': Applied Study, Jordanian Journal of Business Administration, (12) 1,133165.

Abu Zerr, Afaf, E., (2012), ' Financial Reporting and SustainabilityReality and Horizons'- the ninth international scientific professional conference titled: developing the structure of financial reports aftermath the world financial crisis, Amman university, faculty of administration, 2011. 
Adams, A. A. and Gonalez, C. L., (2010), 'Engaging with organizations in pursuit of improved sustainability accounting and performance' Accounting, Auditing and Accountability Journal,20(3), 333-355.

Ali, A. A. (2014)," The importance of sustainability reporting in the evaluation of industrial Jordanian companies: a field study from the Jordanian auditors' perspective", The journal of administration and economics (78).

Badawi M., and Al Beltagi, Y. Accounting in the sustainable development field: between theory and application. The modern office of printing and publishing, Alex, ARE ,2014.

Carey, P., Simnett, R., and Tanewski, G. (2000). "Voluntary demand for internal and external auditing by family business". Auditing: A Journal of Practice and Theory, 19, 37-51

Coates, J., (2013)," Exploring the Rules of the Environmental Crisis: Opportunity for Social Transformation". Critical Social Work, 3(1), 44-66.

Gray, R., (2010), ' Re- evaluation of social, environmental and sustainability accounting: an exploration of an emerging transdisciplinary field? Sustainability Accounting Management and Policy Journal, (1)1, 11-23.

Darwish, Abd-Elnaser, M., (2005),' The Impact of Accounting Disclosure about Environmental Performance of Jordanian Firms on Rationalizing Decisions and the Quality of Financial Reports'. Journal of Faculty of Economy and Administrative Sciences. Jordanian Zytona University.

Deegan, C., Cooper, B. J., \& Shelly, M. (2006). An investigation of TBL report assurance statements: Australian evidence. Australian Accounting Review.

Field, A., (2009), Discovering statistics using SPSS. $3^{\text {rd }}$ Edition, SAGE Publications Ltd., London.

Glaum, M., Baetge, J., Grothe, A., and Oberdörster, T. (2013)." Introduction of International Accounting Standards, Disclosure Quality 
and Accuracy of Analysts' Earnings Forecasts". European Accounting Review.

Global Reporting Initiative (GRI) (2013). "The External Assurance of Sustainability Reporting”. Global Reporting Initiative Research \& Development Series.

Hady, Reda.E., (2006), ' Accounting of Sustainable Environment', The International Scientific Sixth Conference Titled': Ethics of Work and Knowledge Community.' Faculty of Economy and Administrative Sciences, Jordanian Zytona University.

KPMG. (2015), "Currents of Change. The KPMG Survey of Corporate Responsibility Reporting 2015". available at: https://assets.kpmg.com/content/dam/kpmg/pdf/2016/02/kpmg international-survey-of-corporate-responsibility-reporting-2015.pdf.

Leuz, C., \&Verrecchia, R. (2000), "The economic consequences of increased disclosure". Journal of Accounting Research, 38(Supplement), 91-124.

Matar, Mohamed and ElSwetty, Moussa, (2012)' sustainable accounting: Conceptual Framework and Applications in the Professional Practices. A paper submitted to the fourth scientific conference titled: creativity and pioneering in the work organizations, Faculty of Economy and Administrative Sciences, Applied Sciences University. Jordan.

Rajan, Varaun (2016), 'Reporting with Reputation and Returns, The Emerging Significance of Sustainability Accounting', Annual Research Journal of SCMS, 55-66.

Rinaldi, L. and Unerman, J., (2009), Stakeholder Engagement and Dialogue Initiatives of UK, FTSE 100 Companies Over the Internet: An Empirical Analysis, Interdisciplinary Perspectives on Accounting Conference Innsbruck.

Shanan, Ali, A., (2017). 'A Proposed Framework for Measurement and Accounting Disclosure of Sustainable Development in The Con Temporary Egyptian Work Environment' An Applied study. Journal of Accounting Thinking (4) 1. 